удк 338.244.1

DOI https://doi.org/10.32851/2708-0366/2021.7.8

Кацемір Я.В.

кандидат економічних наук,

Херсонський державний аграрно-економічний університет

ORCID: https://orcid.org/0000-0003-2919-4032

Katsemir Yana

Kherson State Agrarian and Economic University

\title{
СТРАТЕГІЧНЕ ПЛАНУВАННЯ І МАРКЕТИНГОВЕ УПРАВЛІННЯ В ГОТЕЛЬНОМУ БІЗНЕСІ
}

\section{STRATEGIC PLANNING AND MARKETING MANAGEMENT IN THE HOTEL BUSINESS}

У сучасному світі з його прискореним ритмом життя значно змінилися і продовжують змінюватися переваги споживачів сфери гостинності. Сучасній людині вже мало просто безпечного даху над головою та елементарного комфорту, їи хочеться нових емоцій, нового досвіду, у результаті чого у неї загострюються почуття краси, історичної пам'яті, усвідомлення себе як члена певної спільноти $і$ m. д., тому в сучасному просторі гостинності з'являються нові стратегії і бізнес-моделі розвитку та просування готельних брендів, щзо відповідають бажанням й інтересам лояльних споживачів, сприяють залученню сегментів ринку готельних послуг. У статті стверджується, шуо на сучасному ринку готельних послуг спостерігається взаємопроникнення компонентів різних стратегій. Кожен з учасників даного ринку сьогодні не обмежує себе традииійним форматом готельного бізнесу.

Ключові слова: готельний бізнес, гостинність, споживач готельних послуг, ринок готельних послуг, стратегічне планування, маркетинг в управлінні.

В современном мире с его ускоряющимся ритмом жизни значительно изменились и продолжают меняться предпочтения потребителей сферы гостеприимства. Современному человеку уже мало просто безопасного крова и элементарного комфорта, ему хочется новых эмочий, нового опыта, в результате чего у него обостряются чувства красотьл, исторической памяти, осознание себя как члена определенного сообщества и т. д., поэтому в современном пространстве гостеприимства появляются новые стратегии и бизнес-модели развития и продвижения гостиничных брендов, отвечающие желаниям и интересам лояльных потребителей и способствующие привлечению сегментов рынка гостиничных услуг. В статье утверждается, что на современном рынке гостиничных услуг наблюдается взаимопроникновение компонентов различных стратегий. Каждый из участников данного рынка сегодня не ограничивает себя традиционным форматом гостиничного бизнеса.

Ключевые слова: гостиничный бизнес, гостеприимство, потребитель гостиничных услуг, рынок гостиничных услуг, стратегическое планирование, маркетинг в управлении.

In the modern world with its accelerating pace of life, the preferences of consumers in the hospitality industry have changed and continue to change. A modern person is no longer just enough safe shelter and elementary comfort, he wants new emotions, new experiences, as a result of which his feelings of beauty, historical memory, awareness of himself as a member of a certain community, etc., are sharpened. Therefore, in the modern hospitality space, new strategies and business models for the development and promotion of hotel brands appear that meet the desires and interests of loyal consumers and help to attract the covered segments of the hotel services market. Today, hotels, in order to survive in the intense competitive professional struggle for a "place in the sun" and in the future to successfully develop as highly profitable and competitive hotel enterprises, need to timely monitor and respond in a timely manner to the emerging needs of already covered segments of hotel consumers, as well as actively seek modern non-standard forms hospitality to attract new segments of consumers. Currently, in the hospitality industry, 
given the growing market for hotel services, and with it the increasing competition among hotel companies, it is important to meet the preferences and tastes of consumers, which are changing significantly due to the ever-accelerating pace of life. That is why the hospitality industry practices, develops and promotes a variety of hotel brands that meet the old and new needs of consumers who are already in the covered market segments, so as not to lose customers, and, of course, contribute to attracting new segments of the hotel market. And here the intuition of anticipating the emergence of these new needs is very important, that is, what modern hotel marketers should have. The article argues that in the modern hotel services market, there is an interpenetration of the components of various strategies. Each of the participants in this market today does not limit himself to the boundaries of the traditional format of the hotel business.

Key words: hotel business, hospitality, consumer of hotel services, market of hotel services, strategic planning, marketing in management.

Постановка проблеми. На сучасному етапі рівень конкуренції в усіх сферах виробництва товарів і надання послуг безперервно зростає, тому будь-якому підприємству необхідне планування як динамічний процес, що дає змогу передбачати й ураховувати зміни, що відбуваються у зовнішньому середовищі, та адаптувати внутрішні чинники виробництва для свого розвитку і подальшого зростання.

Необхідність розроблення і реалізації системи стратегічного планування у готельних підприємствах диктується нестабільністю зовнішнього середовища, підвищенням темпів економічних і соціальних змін, які значно перевершують швидкість реакції готельних господарюючих суб'єктів. Підприємство повинно визначати і прогнозувати параметри зовнішнього середовища, асортимент продукції та послуг, ціни, постачальників, ринки збуту, а найголовніше - свої довгострокові цілі та стратегію їх досягнення. Цю частину роботи й охоплює розроблення стратегічного плану.

Аналіз останніх досліджень і публікацій. Суттєвий внесок у дослідження стратегічного планування та управління готельними підприємствами зробили такі науковці, як А.Д. Чандлер, К. Ендрюс, І. Ансофф [6, с. 29], Г. Мінцберг, Б. Альстренд, Д. Лемпел. Проблеми стратегічного планування у сфері послуг розглядаються в роботах В.Л. Абчука [5, с. 111], В.А. Квартальнова [10, с. 34], Л.П. Дядечко [9, с. 46], однак недостатньо уваги приділено стратегіям підприємств індустрії гостинності.

Формулювання цілей статті. Метою статті є розкриття сутності та особливостей стратегічного планування і маркетингового управління на підприємствах індустрії гостинності.

Виклад основного матеріалу. У готельному бізнесі надійна маркетингова стратегія має вирішальне значення для створення бренду, залучення нових клієнтів і підтримки лояльності. Оскільки лояльність клієнтів $є$ ключовим чинником, менеджери 3 маркетингу і керівники витрачають багато часу та ресурсів на підвищення впізнаваності бренду і створення постійних, взаємопов'язаних кампаній. Ці маркетингові зусилля зазвичай включають у себе як друкований, так і цифровий формат, орієнтований на колишніх гостей, а також на залучення нових клієнтів. Розуміння важливості маркетингу в індустрії гостинності може допомогти вирватися вперед і виділитися на конкурентному ринку праці. Будь-який бізнес може запропонувати кращий продукт на ринку, але без хорошої маркетингової кампанії він не приноситиме бажаного доходу від інвестицій, тому що саме маркетинг робить продукт або послугу відомою для потенційних клієнтів.

Визначення місії в діяльності корпорації є ключовим моментом у будь-якому бізнесі, і применшити значення цього компонента неможливо. Через деякий час керуючі можуть утратити інтерес до первісної мети або ж сама мета може втратити свою актуальність у світлі мінливих умов ринку.

Коли керівництво починає відчувати, що підприємство втрачає свої орієнтири, воно повинно відновити пошуки мети. За словами Пітера Друкера [8], приходить час поставити деякі фундаментальні питання: що являє собою наше підприємство? хто наші клієнти? які у них цінності? яке майбутнє нашого підприємства? яким воно має 
бути? Ці прості, на перший погляд, питання насправді відносяться до числа найскладніших, на які компанія повинна дати відповіді.

Вища мета, до здійснення якої прагне компанія, викристалізовується історично. У кожної компанії є своя історія, в якій було все: цілі, політика, невдачі і звершення. Ресурси підприємства теж зумовлюють вищу мету, до якої воно може прагнути. I, нарешті, підприємство повинно ставити для себе вищу мету, не виходячи за межі своєї компетентності.

Компанія викладає свої вищі цілі в особливій декларації і доводить ії до відома своїх менеджерів, службовців, клієнтів і широкої публіки. Добре написана декларація про головну мету (місію), яку ставить перед собою компанія, сприяє згуртуванню колективу, визначає напрям його діяльності, вселяє у його членів віру у свої можливості [11].

Однак готельна індустрія у стратегічному плануванні має власні специфічні особливості та можливості, оскільки вона значно відрізняється від виробничого сектору економіки. Підприємства готельної та курортної індустрії мають специфіку управління та організаційної структури, що ускладнює процес стратегічного планування:

1. Великі мережі підприємств такого типу зазвичай не володіють усією власністю, якою управляють.

2. Фірми, що займаються управлінням готелів, залишаються невідомими і невидимими для широкої публіки, однак вони можуть володіти й управляти найрізноманітнішою власністю.

3. Керуючі готелями дуже часто не розуміють процесу стратегічного планування. Багато хто вважає, що це сфера відповідальності власників готелів, але якщо власник мало цікавиться роботою готелю, то стратегічним плануванням розвитку власності не займається ніхто.

4. Фірми, керівники готелів, мають недостатньо влади, щоб змусити власника зробити необхідні інвестиції або впровадити стратегічно важливі нововведення. Здебільшого єдиною альтернативою служить відмова від управління цим підприємством.

5. Готелі можуть управляти підприємствами, розташованими на їхній території (ресторани, магазини, медпункти, оздоровчі центри, нічні клуби), але можуть і не мати їх у своєму підпорядкуванні. Це може також створювати додаткові труднощі у стратегічному плануванні.

6. Стратегічні союзи, укладені між мережами готелів на глобальному рівні, часто ускладнюють процес перспективного планування.

Стратегія готельного підприємства $є$ інтегрованою моделлю дій, яка спрямована на досягнення цілей підприємства. Залежно від рівня прийняття рішень на підприємстві використовуються різні види стратегій: корпоративна стратегія (загальна для всього підприємства), стратегія сфери бізнесу, функціональні стратегії (наприклад, маркетингу, фінансова, виробництва, управління персоналом) і т. д.

Відносно підприємства сфери готельного господарства доцільно розглянути поетапний процес формування системи стратегічного управління.

1. Формування загальної стратегії (на даному рівні здійснюється аналіз поточного стану, виявлення слабких і сильних боків підприємства, прогнозування, розроблення стратегічних альтернатив, оцінка та вибір стратегії для всього підприємства).

2. Розроблення стратегічних планів різних бізнес-одиниць (або основних підрозділів підприємства) та їхніх функціональних сфер.

3. Реалізація стратегії (на даному рівні здійснюються оперативні дії з реалізації стратегії, формується база даних, здійснюється координація діяльності різних підрозділів).

4. Стратегічний контроль (аналіз поточного стану підприємства, відповідність запланованих результатів розвитку в рамках запропонованої стратегії фактичним, прийняття рішень про зміну на тому чи іншому рівні).

У даному разі першим кроком $€$ формування основних стратегічних установок і глобальної мети готельного підприємства, що нерозривно пов'язано 3 аналізом 
зовнішнього середовища підприємства. Потім результати роботи конкретизуються у формі портфельної стратегії, а згодом - у формі більш докладної конкурентної стратегії. Залежно від визначених у них цілей і завдань розробляються виробнича, маркетингова, кадрова та фінансова стратегії. У кінцевому підсумку всі зазначені види стратегій формують корпоративну стратегію розвитку, що враховує, таким чином, особливості функціонування усіх підрозділів підприємства. Кінцевим етапом представленого процесу $є$ стратегічний контроль функціонування підприємства, який здійснюється, як правило, у декількох аспектах: на предмет дотримання планових показників, контролю фінансових потоків, контролю чіткого розмежування повноважень різних підрозділів підприємства. Таким чином, під час здійснення стратегічного контролю реалізуються завдання контролю середовища і прогнозування, а його наслідком є можливе розроблення стратегічних альтернатив.

Для розвитку світової готельної індустрії характерні централізація та інтеграція управління, яка поділяється на:

1) вертикальну інтеграцію, що має на увазі комбінацію тих видів діяльності, які становлять технологічну послідовність;

2) горизонтальну інтеграцію, що являє собою об'єднання підприємств, які виробляють однотипний продукт.

Практично всі готельні ланцюги світу незалежно від їхнього рейтингу, відчуваючи на собі постійний тиск жорсткої конкурентної боротьби, шукають будь-які можливості для збільшення свого потенціалу.

Інтеграційні процеси у сфері готельного господарства викликані об'єктивною необхідністю:

- забезпечення стабільного завантаження готелю;

- формування якісної готельної послуги, що залежить від цілої низки чинників: оформлення інтер'єру, якості обладнання, кваліфікації персоналу, забезпечення безпеки проживаючих та їхнього майна;

- прагнення до підвищення рівня завантаження готелю; пошук нових клієнтів і збереження наявних змушують готелі проводити глибокий аналіз ринку, клієнтури, готелів-конкурентів, постачальників і т. д., вести власну рекламну і збутову політику, яка потребує концентрації значних фінансових, інформаційних та людських ресурсів;

- удосконалення професіоналізму персоналу готелів, що істотно впливає на якість обслуговування гостя. Переважна більшість великих готелів не обмежується можливостями підготовки кадрів у державних або комерційних навчальних закладах і створює свою власну систему підготовки та підвищення кваліфікації персоналу, витрачаючи на це значні кошти.

Маркетингове управління являє собою аналіз, планування, реалізацію і контроль над програмами, покликаними цілеспрямовано створювати, будувати і підтримувати взаємовигідні обмінні операції з покупцями цільового ринку заради досягнення стратегічних цілей компанії. Маркетинг і стратегічне планування слід розглядати як партнерський внесок у довгостроковий успіх фірми.

Концепція маркетингу грунтується на тому, що компанії повинні визначати бажання і потреби споживача перш ніж розробляти продукти і сервіси. Ця орієнтація на споживача призводить до більшого попиту на продукцію і послуги фірми та до більш високого рівня задоволеності клієнтів після покупки.

Часи і тенденції швидко змінюються, і дуже важливо, щоб готельний менеджмент йшов у ногу з новітніми цифровими досягненнями і можливостями. Ось кілька ключових трендів готельного маркетингу, які ми можемо виділити сьогодні:

1) Персоналізація. Сьогодні вона використовується в багатьох галузях бізнесу, у тому числі й у готельних мережах. Готелі використовують дані споживачів більш складними способами і розробляють контент, адаптований під кожного клієнта, на основі переваг і онлайн-поведінки. 
2) Mobile is not a trend - це вже звичайний порядок речей, який не варто сприймати як щось нове, як унікальну тенденцію певної індустрії. Мобільні бронювання продовжують рости швидкими темпами, й у цьому році доходи даного сектору досягли позначки в 39 млрд дол., що становить $25 \%$ від загального обсягу ринку онлайн-подорожей [1].

3) Воронка конверсії. Приблизно 98\% відвідувачів веб-сайту готелю залишають воронку, інструменти повернення до бронювання дають змогу вирішити цю проблему - це контекстна реклама або листи-нагадування.

4) Мобільні платежі. Це стало мейнстрімом сфери онлайн-бронювань. За останні два роки в галузі роздрібної торгівлі он-лайн спостерігається сплеск альтернативних способів оплати, таких як PayPal, i зараз один із чотирьох платежів по цих каналах мобільні транзакції.

5) Pay to play. Соціальні платформи продовжуватимуть вносити значні зміни у свої алгоритми, які впливатимуть на охоплення контенту рекламного характеру.

6) Готелі повинні стати максимально клієнтоорієнтованими, менеджери повинні дивитися на готель саме через призму клієнта, а не свого маркетолога. Індустрії гостинності необхідно чітко розуміти, чого персонально хочуть їхні клієнти, чого вони потребують, й адаптувати під це свою діяльність.

7) Програмний маркетинг. Варто налаштуватися на справжній вибух програмних торгів протягом найближчих років. Нині $35 \%$ від загального обсягу рекламних витрат витрачається на показ реклами, купленої саме через програмні технології. У цю концепцію вбудовується і поява таких інструментів, як біржа реклами в різних соціальних мережах, у тому числі Тік-Ток, Facebook і т. д.

8) Аудіовізуальний контент. Дослідження показують, що люди запам'ятовують $10 \%$ почутого, $20 \%$ прочитаного і $80 \%$ із того, що вони побачили або зробили самі. Ми бачимо значне зростання візуального сторітеллінга, який дає змогу готелям будувати живе спілкування.

9) Безпосередня близькість технологій. 91\% власників смартфонів стверджує, що взагалі не розлучається зі своїм телефоном, він знаходиться 3 ними 24 години на добу, сім днів на тиждень. Зрозуміло, маркетологи готелів можуть отримувати із цього вигоду - використовувати геомаркетинг, де різні повідомлення можуть «досягати» користувачів залежно від місця розташування.

10) Цілісний підхід до управління доходами. Швидка зміна споживчої поведінки вимагає від власників бізнесу використання комплексного підходу до управління доходами 3 найбільшим впливом відділів продажів і маркетингу в процесі прийняття рішень. Зближення їхніх ролей має вирішальне значення для ефективного управління каналами розподілу.

Висновки. Незважаючи на несприятливі обставини останніх років, індустрія гостинності залишається дуже перспективним сектором економіки (навіть під час економічної кризи). Однак щоб зміцнити ринкові позиції у конкурентній боротьбі, готельні підприємства повинні постійно вдосконалювати спосіб надання послуг, шукати резерви для підвищення продуктивності та поліпшувати якість і культуру обслуговування.

Необхідність розроблення й упровадження системи стратегічного планування на готельних підприємствах продиктована зростаючою нестабільністю зовнішнього середовища, збільшенням темпів його економічних та соціальних змін, які значно перевищують рівень реакції суб'єктів готельного бізнесу. Наукове обгрунтування створення ефективно функціонуючої системи стратегічного планування розвитку готелів, підвищення рівнів ефективності використання ресурсів $є$ умовами досягнення бажаних показників ефективності в перспективний та стратегічний періоди часу. 


\section{Список використаних джерел:}

1. Hotel Marketing Trends for 2015. AdWeek. URL: http://www.adweek.com/socialtimes/hotelmarketing-trends-2015/612585.

2. Ting, D. More Hotels Are Planning to Use Location-Based Services to Interact With Guests. Skift. URL: https://skift.com/2016/12/14/more-hotels-are-planning-to-use-location-based-services-tointeract-with-guests.

3. Top five hotel technology trends. URL: https://www.tnooz.com/article/hotel-technologytrends-erevmax.

4. Yurii Kyrylov, Viktoriia Hranovska, Viktoriia Boiko, Aleksy Kwilinski, Liudmyla Boiko. International Tourism Development in the Context of Increasing Globalization Risks: On the Example of Ukraine's Integration into the Global Tourism Industry. Journal of Risk and Financial Management. 2020. № 13. P. 303. URL: https://doi.org/10.3390/jrfm13120303.

5. Абчук В.Л. Лекції з менеджменту. Рішення. Передбачення. Санкт-Петербург : Союз. 1999. 336 с.

6. Ансофф І. Стратегічне управління / пер. з англ. Москва : Економіка. 1989. 306 с.

7. Економіка туризму : навчальний посібник / В.Г. Грановська та ін. Херсон : ОЛДІ-ПЛЮС, 2020. 208 c.

8. Друкер П.Ф., Макьярелло Дж.А. Менеджмент / пер. $з$ англ. Москва : ООО "В.Д. Вільямс". 2010. 704 с.

9. Дядечко Л.П. Економіка туристичного бізнесу. Київ : Центр учбової літератури. 2007. 224 с.

10. Квартальнов В.А. Стратегічний менеджмент в туризмі. Москва : Фінанси і статистика, 1999. $496 \mathrm{c}$.

11. Котлер Ф., Боуен Дж., Мейкенз Дж. Маркетинг. Гостинність і туризм : підручник. Москва : Юніті. 1998. 787 с.

12. Трусова Н.В., Грановська В.Г., Крикунова В.М. Ринок туристичних послуг та поляризація туристичної системи. Збірник наукових праць Таврійського державного агротехнологічного університету імені Дмитра Моторного (економічні науки). 2020. № 2(42). С. 65-72.

\section{References:}

1. Hotel Marketing Trends for 2015. AdWeek. Available at: http://www.adweek.com/socialtimes/ hotel-marketing-trends-2015/612585.

2. Ting, D. More Hotels Are Planning to Use Location-Based Services to Interact With Guests. Skift. Available at: https://skift.com/2016/12/14/more-hotels-are-planning-to-use-location-based-services-to-interact-with-guests.

3. Top five hotel technology trends. Available at: https://www.tnooz.com/article/hotel-technology-trends-erevmax.

4. Yurii Kyrylov, Viktoriia Hranovska, Viktoriia Boiko, Aleksy Kwilinski, Liudmyla Boiko. (2020) International Tourism Development in the Context of Increasing Globalization Risks: On the Example of Ukraine's Integration into the Global Tourism Industry. Journal of Risk and Financial Management, no. 13, p. 303. DOI: https://doi.org/10.3390/jrfm13120303.

5. Abchuk V.L. (1999) Lektsii z menedzhmentu. Rishennia. Peredbachennia [Lectures on management. Decision. Foresight]. Saint-Peterburgh: Sojuz. (in Ukrainian)

6. Ansoff I. (1989) Stratehichne upravlinnia [Strategic management]. Moscow: Ekonomika. (in Ukrainian)

7. Hranovska V.H., Krykunova V.M., Morozova O.S., Katsemir Ya.V., Boiko V.O., Duha V.O. (2020) Ekonomika turyzmu [Economics of tourism]. Kherson: OLDI-PLUS. (in Ukrainian)

8. Druker P.F., Makiarello Dzh.A. (2010) Menedzhment [Management]. Moscow: OOO "V.D. Viljjams". (in Ukrainian)

9. Diadechko L.P. (2007) Ekonomika turystychnoho biznesu [Economics of tourism business]. Kyiv: Centr uchbovoji literatury. (in Ukrainian)

10. Kvartalnov V.A. (1999) Stratehichnyi menedzhment v turyzmi [Strategic management in tourism]. Moscow: Finansy i statystyka. (in Russian)

11. Kotler F., Bouen Dzh., Meikenz Dzh. (1998) Marketynh. Hostynnist i turyzm [Marketing. Hospitality and tourism]. Moscow: Uniti. (in Ukrainian)

12. Trusova N.V., Hranovska V.H., Krykunova V.M. (2020) Rynok turystychnykh posluh ta poliaryzatsiia turystychnoi systemy [Tourist services market and polarization of the tourist system]. Zbirnyk naukovykh prats Tavriiskoho derzhavnoho ahrotekhnolohichnoho universytetu imeni Dmytra Motornoho (ekonomichni nauky), no. 2 (42), pp. 65-72. 